\title{
RECEIVED
}

FEB 161999

OSTI

\section{Novel Approaches To The Production of Higher Alcohols From Synthesis Gas}

\author{
Quarterly Report \\ January 1 - March 31, 1996 \\ By \\ George W. Roberts
}

Work Performed Under Contract No.: DE-AC22-90PC90043

For

U.S. Department of Energy Office of Fossil Energy

Federal Energy Technology Center

P.O. Box 880

Morgantown, West Virginia 26507-0880

By

North Carolina State University

Department of Chemical Engineering

Box 7905

Raleigh, North Carolina 27695-7905 


\section{Disclaimer}

This report was prepared as an account of work sponsored by an agency of the United States Government. Neither the United States Government nor any agency thereof, nor any of their employees, makes any warranty, express or implied, or assumes any legal liability or responsibility for the accuracy, completeness, or usefulness of any information, apparatus, product, or process disclosed, or represents that its use would not infringe privately owed rights. Reference herein to any specific commercial product, process, or service by trade name, trademark, manufacturer, or otherwise does not necessarily constitute or imply its endorsement, recommendation, or favoring by the United States Government or any agency thereof. The views and opinions of authors expressed herein do not necessarily state or reflect those of the United States Government or any agency thereof. 


\section{DISCLAIMER}

Portions of this document may be illegible in electronic image products. Images are produced from the best available original document. 


\section{NOTICE}

This report contains information which is potentially patentable. U.S. patent applications covering these concepts may be filed with the U.S. Patent Office. As per instructions from the Office of Patent Counsel, US Department of Energy, Argonne, Illinois, the following notice is in effect:

\section{Patent Hold}

This document copy, since it is transmitted in advance of patent clearance, is made available in confidence solely for use in performance of work under contracts with the U.S. Department of Energy. This document is not to be published nor its contents otherwise disseminated or used for purposes other than specified above before patent approval for such release or use has been secured, upon request, for Chief, Office of Patent Counsel, U.S. Department of Energy, 9800 South Cass Avenue, Argonne, Illinois 60439. 


\section{NOVEL APPROACHES TO THE PRODUCTION OF HIGHER \\ ALCOHOLS FROM SYNTHESIS GAS \\ Quarterly Technical Progress Report \\ January 1, 1996 to March 31, 1996}

\section{CONTRACT OBJECTTVES}

Task 1. Program Management.

Task 2. Liquid-Phase, Higher Alcohol Process with Recycle of Lower Alcohols.

Task 3. Novel Catalysts for Synthesis of Higher Alcohols. (Complete)

Task 4. Synthesis of Higher Alcohols via Acid-Base Catalysis. (Complete)

Task 5. Technology Evaluation. (Complete)

\section{SUMMARY}

Effort during this quarter was devoted to three areas: 1) analyzing the data from earlier runs with "zinc chromite" catalyst and three different slurry liquids: decahydronaphthalene (Decalin $\left.{ }^{\circledR}, \mathrm{DHN}\right)$, tetrahydronaphthalene (tetralin, THN) and tetrahydroquinoline (THQ); 2) analyzing newly-obtained data from earlier thermal stability tests on DHN and THN, and; 3) carrying out a thermal stability test on THQ.

Both the activity and selectivity of "zinc chromite" catalyst depended on the slurry liquid that was used. The catalyst activity for methanol synthesis was in the order: $T H Q>D H N>T H N$. Despite the basic nature of THQ it exhibited the highest dimethyl ether (DME) production rates of the three liquids.

Gas chromatography/mass spectroscopy (GC/MS) analyses of samples of THN and DHN were taken at the end of standard thermal stability tests at $375^{\circ} \mathrm{C}$. With both liquids, the only measurable compositional change was a minor amount of 
isomerization. Analysis of a sample of THN after a thermal stability test at $425^{\circ} \mathrm{C}$ showed a small reduction in molecular weight, and a significant amount of opening of the naphthenic ring.

Preliminary data from the thermal stability test of THQ showed that this molecule is more stable than DHN, but less stable than THN.

\section{TECHNICAL DETAILS}

\section{A. Effect of Slurry Liquid on Catalyst Performance}

Table 1 presents a summary of the results of several experiments with Engelhard "zinc chromite" ( $\mathrm{ZnCrO}$ ) catalyst ( $\mathrm{Zn}-0312 \mathrm{~T} \mathrm{1/8)}$ and three different liquid media: tetrahydroquinoline (THQ), tetrahydronaphthalene (THN, tetralin) and decahydronaphthalene (DHN, Decalin ${ }^{\circledR}$ ). The data for THQ and THN was taken during December, 1995. The DHN data was obtained in June, 1995. In each liquid, data was obtained at four different experimental conditions: 1) temperature = $325^{\circ} \mathrm{C} ; \mathrm{H}_{2} / \mathrm{CO}$ ratio (feed) $=0.5 ; 2$ ) temperature $=325^{\circ} \mathrm{C} ; \mathrm{H}_{2} / \mathrm{CO}$ ratio (feed) $=2.0 ; 3$ ) temperature $=375^{\circ} \mathrm{C}, \mathrm{H}_{2} / \mathrm{CO}$ ratio (feed) $=0.50 ;$ and; 4 ) temperature $=375^{\circ} \mathrm{C}, \mathrm{H}_{2} / \mathrm{CO}$ ratio (feed) $=2.0$. All runs were at a total pressure of $2000 \mathrm{psig}$ and a gas hourly space velocity (GHSV) of $5000 \mathrm{sl} / \mathrm{kg}$. cat.-hr.

THQ exhibited the best methanol productivity among the studied liquids. At all four conditions, the methanol catalyst productivity, i.e., the rate of methanol formation ( $\mathrm{Rm}$ ) was greater in THQ than in either DHN or THN. Moreover, the rate of methanol formation was generally higher in DHN than in THN. Comparison of THQ and DHN shows the largest methanol productivity differences at a $\mathrm{H}_{2} / \mathrm{CO}$ ratio of 2 . At both $325^{\circ} \mathrm{C}$ and $375^{\circ} \mathrm{C}$, with $\mathrm{H}_{2} / \mathrm{CO}=2$, the catalyst productivity was 2-3 times higher in THQ than in DHN. At a $\mathrm{H}_{2} / \mathrm{CO}$ ratio of 0.5 , the catalyst was still more active in THQ than in decalin, but the activity difference was 


\section{Table 1}

Comparison of Catalyst Performance in Tetrahydronaphthalene (THN), Decahydronaphthalene (DHN) and Tetrahydroquinoline (THQ)*

$\underline{T H N} \quad \underline{D H N} \quad \underline{T H O}$

$\mathrm{T}=325^{\circ} \mathrm{C}_{2} \mathrm{H}_{2} / \mathrm{CO}=2$

Average $\mathrm{Rm}$ ( $\mathrm{mol} \mathrm{MeOH} / \mathrm{kg}$-hr)

2.50

5.62

12.7

Mole \% DME (effluent)

0.033

0.045

0.17

Mole \% $\mathrm{MeOH}$ (effluent)

1.38

2.95

7.64

$\mathrm{T}=325^{\circ} \mathrm{C}_{1} \mathrm{H}_{2} / \mathrm{CO}=0.5$

Average $\mathrm{Rm}$ ( $\mathrm{mol} \mathrm{MeOH} / \mathrm{kg}$-hr)

1.49

5.85

7.23

Mole \% DME (effluent)

0.010

0.011

0.15

Mole \% $\mathrm{MeOH}$ (effluent)

0.85

3.02

3.99

$\mathrm{T}=375^{\circ} \mathrm{C}, \mathrm{H}_{2} / \mathrm{CO}=2$

Average $\mathrm{Rm}$ (mole $\mathrm{MeOH} / \mathrm{kg}-\mathrm{hr}$ )

3.71

3.22

9.15

Mole \% DME (effluent)

0.04

0.145

0.29

Mole \% $\mathrm{MeOH}$ (effluent)

2.20

1.38

5.28

$\mathrm{T}=375^{\circ} \mathrm{C}, \mathrm{H}_{2} / \mathrm{CO}=0.5$

Average $\mathrm{Rm}$ (mole $\mathrm{MeOH} / \mathrm{kg}-\mathrm{hr}$ )

1.61

2.37

2.57

Mole \% DME (effluent)

0.020

0.20

0.260

Mole.\% MeOH (effluent)

0.95

1.01

1.42

*Constant conditions for all runs:

Total pressure - $2000 \mathrm{psig}$

GHSV - $5000 \mathrm{sl} / \mathrm{kg}$ (cat)-hr (average)

Stirrer speed - $1750 \mathrm{rpm}$

Engelhard $\mathrm{Zn}-0312 \mathrm{~T} 1 / 8$ catalyst 
not as great. At $375^{\circ} \mathrm{C}$ and $\mathrm{H}_{2} / \mathrm{CO}=0.5$, the reaction was about halfway to equilibrium, which tended to obscure differences in catalyst activity.

In the case of the two hydrocarbon liquids (THN and DHN), the completely saturated one (DHN) exhibited higher methanol productivity. The greatest difference was at $325^{\circ} \mathrm{C}$, where productivities and concentrations were 2-4 fold higher in DHN. At $375^{\circ} \mathrm{C}$, the catalyst productivity differences were smaller.

Surprisingly, the rate of dimethyl ether formation was higher with THQ than with DHN or THN. This can be seen in Table 1 from the fact that the effluent DME concentration was always higher for THQ than for the other two liquids. The relative differences were much greater at $325^{\circ} \mathrm{C}$ than at $375^{\circ} \mathrm{C}$. One of the original motivations for testing THQ, a basic secondary amine, was to neutralize the acidity of "zinc chromite" catalyst, thereby suppressing reactions such as methanol dehydration to DME and alcohol dehydration. The present data suggest that THQ is not effective in neutralizing whatever surface acidity leads to DME.

The mechanism by which THQ promotes the methanol synthesis reaction is not clear at this time. However, the fact that the methanol catalyst productivity is higher in DHN than in THN might be attributed to competitive adsorption on catalyst sites, associated with the aromaticity of THN.

\section{B. Thermal Stability of DHN and THN}

Tables 2 through 5 show the results of gas chromatography/mass spectroscopy (GC/MS) analyses carried out on samples of DHN (decahydronaphthalene) and THN (tetrahydronaphthalene) taken at the end of standard thermal stability tests (TST) on these two compounds. These TST's were carried out in November, 1994 (DHN), September 1995 (THN - 375 ${ }^{\circ} \mathrm{C}$ ) and October, 1995 (THN - 425ㅇ). The principal results of these tests were presented and discussed in the Monthly Reports 
for these three periods, and in the corresponding Quarterly Reports. Table 6 summarizes the conditions of the TST.

Tables 2 and 3 show that the only significant change between fresh DHN and the sample taken at the end of the TST was a minor amount of cis/trans isomerization. No other compounds were detected. There was no change in molecular weight over the course of the test.

Table 4 shows that the only significant change that occurred during the TST with tetralin at $375^{\circ} \mathrm{C}$ was a small amount of isomerization to 2,3-dihydro-1methylindene, although the exact location of the methyl group is not certain. The final liquid was $96 \% \mathrm{THN}$, and it had the same average molecular weight as fresh THN. The absence of a detectable concentration of 2,3-dihydroindene suggests that dealkylation of the 2,3-dihydromethylindene is not rapid.

Table 5 shows that carrying out the TST with THN at $425^{\circ} \mathrm{C}$ instead of the standard temperature of $375^{\circ} \mathrm{C}$ resulted in the formation of about 4 mole $\%$ of species with a lower carbon number, namely toluene and ethyl benzene, and in a $1 \%$ reduction in the average molecular weight. However, about 22 mole \% of liquid was alkyl aromatics, indicating a significant amount of opening of the naphthenic ring of THN. At this temperature, a minor amount of dehydrogenation to naphthalene also occurred. 
Table 2

Estimated Composition and Molecular Weight of Fresh Decalin (Decahydronaphthalene) $\vdots 1$

\begin{tabular}{|c|c|c|c|c|c|c|c|}
\hline Component & $\begin{array}{l}\text { Retention } \\
\text { time (min) }\end{array}$ & $\begin{array}{l}\text { Probability } \\
\text { (\% accuracy) }\end{array}$ & $\begin{array}{l}\text { Peak } \\
\text { Area } \\
\end{array}$ & $\begin{array}{l}\text { Molecular } \\
\text { Formula }\end{array}$ & $\begin{array}{c}\mathrm{MW} \\
(\mathrm{gr} / \mathrm{mol})\end{array}$ & $\mathrm{mol} \%$ & wt \% \\
\hline $\begin{array}{c}\text { Trans-decahydronaphthalene } \\
\text { Cis-decahydronaphthalene } \\
\text { Total Area }\end{array}$ & $\begin{array}{c}9.88 \\
10.67\end{array}$ & $\begin{array}{l}98 \\
94\end{array}$ & $\begin{array}{l}5858631 \\
3313638 \\
9172269\end{array}$ & $\begin{array}{l}\mathrm{C} 10 \mathrm{H} 18 \\
\mathrm{C} 10 \mathrm{H} 18\end{array}$ & $\begin{array}{l}138 \\
138\end{array}$ & $\begin{array}{l}63.9 \\
36.1 \\
100\end{array}$ & $\begin{array}{l}63.9 \\
36.1 \\
100\end{array}$ \\
\hline Average $\mathrm{MW}(\mathrm{gr} / \mathrm{mol})$ & & & & & 138 & & \\
\hline
\end{tabular}

Table 3

Estimated Composition and Molecular Weight of Decalin Following a TST at $375^{\circ} \mathrm{C}$

\begin{tabular}{|c|c|c|c|c|c|c|c|}
\hline Component & $\begin{array}{l}\text { Retention } \\
\text { time (min) }\end{array}$ & $\begin{array}{l}\text { Probability } \\
\text { (\% accuracy) }\end{array}$ & $\begin{array}{l}\text { Peak } \\
\text { Area }\end{array}$ & $\begin{array}{l}\text { Molecular } \\
\text { Formula }\end{array}$ & $\begin{array}{c}\mathrm{MW} \\
(\mathrm{gr} / \mathrm{mol})\end{array}$ & $\mathrm{mol} \%$ & wt $\%$ \\
\hline $\begin{array}{l}\text { Trans-decahydronaphthalene } \\
\text { Cis-decahydronaphthalene }\end{array}$ & $\begin{array}{c}9.99 \\
10.77\end{array}$ & $\begin{array}{l}87 \\
86\end{array}$ & $\begin{array}{l}15415882 \\
9829730 \\
25215610\end{array}$ & $\begin{array}{l}\text { C10H18 } \\
\text { C10H18 }\end{array}$ & $\begin{array}{l}138 \\
138\end{array}$ & $\begin{array}{l}61.1 \\
38.9 \\
\end{array}$ & $\begin{array}{l}61.1 \\
38.9 \\
100\end{array}$ \\
\hline
\end{tabular}

Average MW (gr/mol) 
Table 4

Estimated Composition and Molecular Weight of Tetralin Following a TST at $375^{\circ} \mathrm{C}$

$\vdots 1$

\begin{tabular}{|c|c|c|c|c|c|c|c|}
\hline Component & $\begin{array}{l}\text { Retention } \\
\text { time (min) }\end{array}$ & $\begin{array}{c}\text { Probability } \\
(\% \text { accuracy })\end{array}$ & $\begin{array}{l}\text { Peak } \\
\text { Area }\end{array}$ & $\begin{array}{l}\text { Molecular } \\
\text { Formula }\end{array}$ & $\begin{array}{c}\mathrm{MW} \\
\text { (gr/mol) }\end{array}$ & $\mathrm{mol} \%$ & wit \% \\
\hline $\begin{array}{c}\text { 2, 3-dihydro-1-methyl-indene } \\
\text { Tetralin }\end{array}$ & $\begin{array}{l}10.26 \\
\mathbf{1 1 . 8 0}\end{array}$ & $\begin{array}{l}86 \\
97\end{array}$ & $\begin{array}{l}248449 \\
6261320\end{array}$ & $\begin{array}{l}\mathrm{C} 10 \mathrm{H} 12 \\
\mathrm{C} 10 \mathrm{H} 12\end{array}$ & $\begin{array}{l}132 \\
132\end{array}$ & $\begin{array}{c}3.8 \\
96.2\end{array}$ & $\begin{array}{r}3.8 \\
96.2\end{array}$ \\
\hline $\begin{array}{c}\text { Unknowns }\left(\mathrm{BP}>300^{\circ} \mathrm{C}\right)(*) \\
\text { Total Area }\end{array}$ & - & - & $\frac{0}{\overline{6509769}}$ & . & - & $\begin{array}{c}0.0 \\
100\end{array}$ & $\frac{0.0}{100}$ \\
\hline
\end{tabular}

Average MW (gr/mol)

138

\% MW reduction

none 
$\because \quad \because$

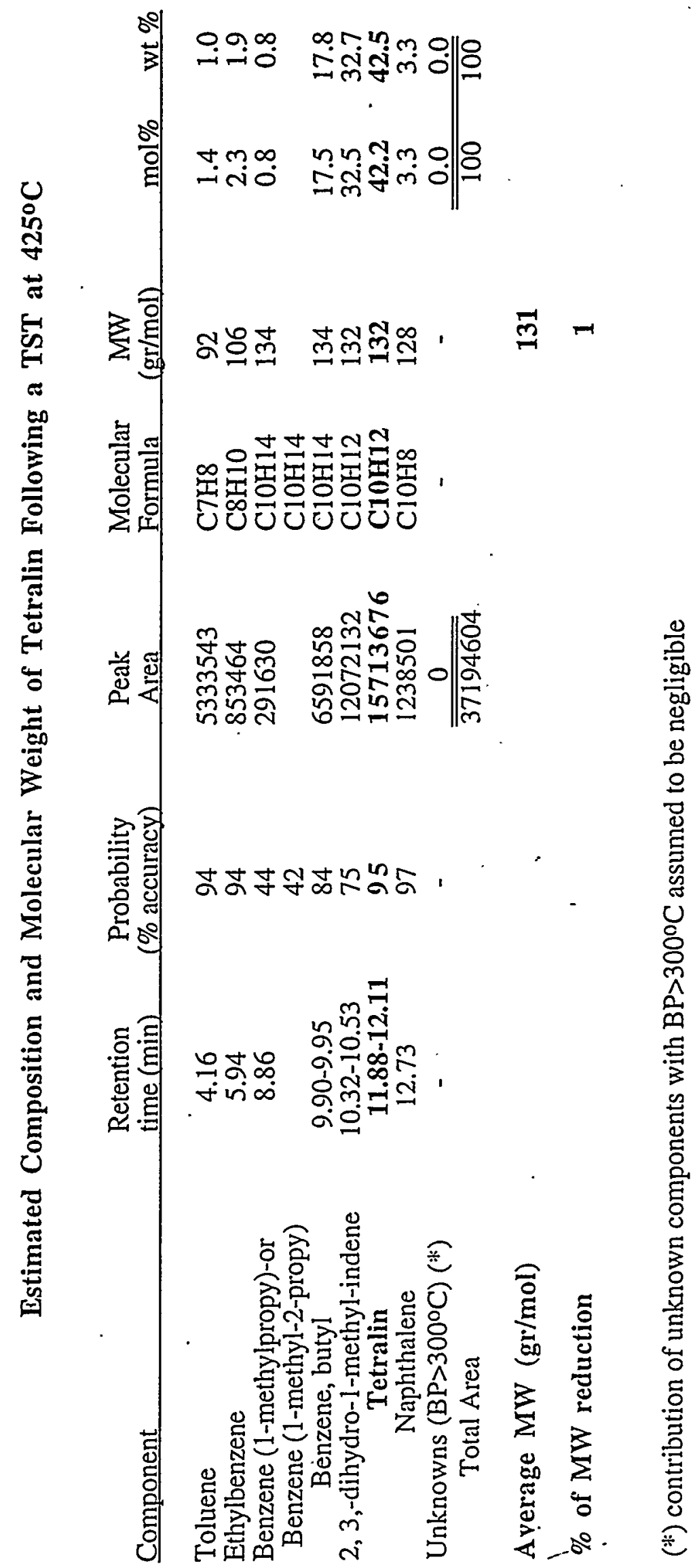


Table 6

\section{Conditions of Thermal Stability Test (TST)}

Reactor Temperature:

Reactor Pressure:

Length of Test:

Gas/Liquid Separator Temperature:

$\mathrm{H}_{2}$ Flowrate:

No Catalyst Present $375^{\circ} \mathrm{C}$

1000 psig

72 hours after reaching $375^{\circ} \mathrm{C} *$

$25^{\circ} \mathrm{C}$

$3.5 \mathrm{sL} / \mathrm{min}$.

*Unless otherwise noted 


\section{Thermal Stability Test with THQ}

A standard thermal stability test (TST) was carried out on tetrahydroquinoline (THQ) at the conditions shown in Table 6. Some of the results from this experiment, along with a summary of the results of earlier TST's is shown in Table 7. In terms of gas production, THQ is one of the more stable liquids tested, with a steady-state $C_{1}-C_{4}$ gas production rate of only $0.008 \%$ of the initial charge $/ \mathrm{hr}$. The total liquid loss over the duration of the test, $9 \%$, was also excellent. The results of gas chromatography/mass spectroscopy analysis of the liquid remaining at the end will be discussed in the next quarterly report.

\section{Miscellaneous}

A technical paper entitled "Alcohol Synthesis in a High-Temperature Slurry Reactor" was prepared and presented at the Symposium on Syngas Conversion to High Value Chemicals. This symposium was held at the 211th National Meeting of the American Chemical Society, New Orleans, LA, March 27-29, 1996. A copy of the manuscript is appended. 
Table 7

Summary of the Results of Thermal Stability Tests

\begin{tabular}{|c|c|c|c|c|c|c|c|}
\hline \multirow[t]{2}{*}{ Liquid } & \multicolumn{2}{|c|}{$\begin{array}{c}\text { Rate of } \mathrm{C}_{1}-\mathrm{C}_{4} \text { gas production } \\
(\mathrm{g} / \mathrm{hr})\end{array}$} & \multicolumn{2}{|c|}{$\begin{array}{l}\text { Rate of } \mathrm{C}_{1}-\mathrm{C}_{4} \text { gas production } \\
\text { (\% initial charge/hr) }\end{array}$} & \multirow{2}{*}{$\begin{array}{l}\text { Total weight of } \mathrm{C}_{1}-\mathrm{C}_{4} \\
\text { gases produced during } \\
\text { the test }(\mathrm{g})\end{array}$} & \multirow{2}{*}{$\begin{array}{l}\text { Weight of liquid } \\
\text { lost via } C_{1}-C_{4} \text { gases } \\
\text { (\% of initial charge) }\end{array}$} & \multirow{2}{*}{$\begin{array}{l}\text { Total weight of } \\
\text { liquid lost (\% } \\
\text { of initial charge) }\end{array}$} \\
\hline & $\overline{\text { Maximum }}$ & $\overline{\text { Steady State }}$ & Maximum & $\overline{\text { Steady State }}$ & & & \\
\hline Durasyn 180 & 2.3 & 0.15 & 1.8 & 0.12 & - & - & 65 \\
\hline Drakeol 34 & 1.6 & 0.013 & 1.2 & 0.10 & - & - & 59 \\
\hline Decalin & $0: 13$ & 0.0053 & 0.095 & 0.0040 & - & - & 26 \\
\hline PHF & 0.61 & 0.061 & 0.44 & 0.044 & - & - & 9.0 \\
\hline DHQ & 0.17 & 0.066 & 0.17 & 0.066 & 5.2 & 5.2 & 31 \\
\hline $134 \mathrm{PPDP}$ & 0.22 & 0.0019 & 0.22 & 0.002 & 1.7 & 1.7 & 30 \\
\hline NB37 & 0.42 & 0.13 & 0.42 & 0.13 & 16 & 16 & 41 \\
\hline Tetralin & 0.019 & 0.0036 & 0.012 & 0.002 & 0.19 & 0.12 & 13 \\
\hline $\begin{array}{l}\text { Tetralin@ } \\
425^{\circ} \mathrm{C}\end{array}$ & 0.063 & 0.024 & 0.041 & 0.015 & 2.6 & 1.6 & 10 \\
\hline THQ & 0.16 & 0.013 & 0.10 & 0.008 & 3.4 & 2.2 & 9.0 \\
\hline
\end{tabular}




\section{SYNGAS CONVERSION TO HIGH VALUE CHEMICALS MARCH 24-29, 1996; NEW ORLEANS, LA}

\section{ALCOHOL SYNTHESIS IN A HIGH-TEMPERATURE SLURRY REACTOR}

Marco A. Márquez, M. Shawn MicCutchen and George W. Roberts**

Department of Chemical Engineering, North Carolina State University, Box 7905

Raleigh, NC 27695-7905

*Present address: E. I. duPont de Nemours and Company, Inc.,

Jackson Laboratory, Chambers Works, Deepwater, NJ 08023

**To whom correspondence should be addressed (919-515-7328)

Key Words: Alcohol, Decahydronaphthalene, Methanol, Slurry Reactor, Zinc Chromite

\section{ABSTRACT}

A laboratory stirred autoclave reactor has been developed to operate at temperatures up to $375^{\circ} \mathrm{C}$ and pressures of at least 170 atma. The periormance of a commercial "high pressure" methanol synthesis catalyst, the so-called "zinc chromite" catalyst, has been characterized over a range of temperature from 275 to $375^{\circ} \mathrm{C}$, pressures from 68 to 170 atma, $\mathrm{H}_{2} / \mathrm{CO}$ ratios from 0.5 to 2.0 and space velocities from 1,500 to $10,000 \mathrm{sL} / \mathrm{kg}$ (catalyst)-hr. Iowards the lower end of the temperature range, methanol was the only significant product. At the highest temperatures, the methanol synthesis reaction was close to equilibrium and there were significant quantities of methane, dimethyl ether and olefins in the product.

\section{INTRODUCTION}

The synthesis of higher $\left(\mathrm{C}_{2}^{+}\right)$alcohols from mixtures of $\mathrm{H}_{2}$ and $\mathrm{CO}$ (synthesis gas) has been an active area of research for the last several decades. Heydorn et al. (1) and Minahan and Nagaki (2) have pointed out the advantages of an alcohol synthesis process that produces approximately one mole of methanol (or ethanol) and one mole of a 2-methyl 1-alcohol, e.g., isobuisnol or 2-methyl 1-butanol. Such a product distribution could support the production of established octane enhancers such as methyl tertiary butyl ether (MTEE); ethyl tertiary butyl ether (ETBE) and tértiary amyl methyl ether (TAME), with relatively small amounts of 
methanol, ethanol, propanol, etc. that would have to be sold as by-products. Certain modified methanol synthesis catalysts have yielded product distributions in which methanol and isobutanol are the predominant products (1-6). None of these catalysts appear to be completely satisfactory, either because the molar rate of methanol formation has been much greater than that of isobutanol formation and/or because the overall rate of alcohol formation has been low.

The synthesis of alcohols, particularly $\mathrm{C}_{2}^{+}$alcohols, is highly exothermic. Excellent temperature control is essential to good selectivity, to long catalyst life and, in the case of methanol synthesis, to high conversions because of the reversibility of the reaction. A siurry reactor provides an essentially isothermal reaction environment, on both the scale of the reactor and the scale of the catalyst particle. Therefore, this type of reactor has received a great deal of attention for methanol synthesis (7-9), for dimethyl ether synthesis (10), for the dehydration of isobutanol (11) and for the synthesis of higher alcohols $(1,12)$.

Most previous studies of alcohol synthesis and related reactions in slurry reactors have been carried out at temperatures below about $310^{\circ} \mathrm{C}$, for several reasons. First, most of the previous work has involved catalysts, such as the $\mathrm{Cu} / \mathrm{ZnO}$ "low pressure" methanol synthesis catalyst, that deactivate rapidly above about $300^{\circ} \mathrm{C}$ (8). Second, the liquids that traditionally have been used to slurry the catalyst are unstable in the presence of high partial pressures of $\mathrm{H}_{2}$ at temperatures significantly in excess of $300^{\circ} \mathrm{C}$.

The specific objectives of this work were to extend the operating range of slurry . reactors for alcohol synthesis to a temperature of about $375^{\circ} \mathrm{C}$, and to characterize' the performance of a "zinc chromite", "high-pressure" methanol synthesis catalyst in a slurry reactor at iemperatures up to $375^{\circ} \mathrm{C}$. This research is intended to set the stage for the synthesis and evaluation of promoted "zinc chromite" catalysts for the production of higher alcohols.

\section{EQUIPMENT}

Gases were fed from cylinders through activated carbon traps to remove impurities, including metal carbonyls, and then through mass How controllers to measure and control the flow rates. The individual gas streams were mixed and 
compressed to the desired pressure. The compressed gas was passed through another activated carbon trap to remove any iron and/or nickel carbonyls that may have formed during and after compression. The gas was then fed into a 300 $\mathrm{cm}^{3}$ stirred autoclave reactor. The gas leaving the reactor passed into a gas/liquid separator containing a cooling coil that served to control the temperature of the separator. The gas then passed through a back pressure regulator, through heated lines to prevent condensation and through a wet test meter to measure the gas flow rate. Samples of the reactor feed and effluent were periodically diverted to a dual-column gas chromatograph containing a Carboxen 1000 column followed by a thermal conductivity detector and a Poroplot $Q$ column followed by a flame ionization detector. The former system was used to measure the fixed gases, $\mathrm{H}_{2}, \mathrm{~N}_{2}, \mathrm{CO}, \mathrm{CO}_{2}$ and $\mathrm{H}_{2} \mathrm{O}$. The organic species were measured on the second system. Further details can be found in reference (13).

\section{RESULTS AND DISCUSSION}

\section{Liquid Stability Testing}

The "zinc chromite" catalyst is typically run at temperatures of 350 to $410^{\circ} \mathrm{C}$ in commercial, fixed-bed methanol synihesis reactors (1 1 -16). Moreover, research on the addition of alkali metals to this catalyst, aimed at shifting the product distribution towards the higher alconols (-ㅡㄴ), has involved similar temperatures. Therefore, an initial target temperature of $375^{\circ} \mathrm{C}$ was set for slurry reactor operation.

A "thermal" stability test was carried out by charging a measured amount of the liquid to the stirred autoclave reactor, pressurizing to 69 atma with $\mathrm{H}_{2}$, heating to $375^{\circ} \mathrm{C}$, continuously sparging $\mathrm{H}_{2}$ through the liquid and holding the system at these conditions for about three days. Catalyst was not present during this test. The gas leaving the reactor was analyzed periodically by gas chromatography to determine whether any hydrocarbons were present, and, if so, their identities and concentrations. At the end of the test period, a number of analyses were carried out on the liquid remaining in the reactor, including molecular weight, density, refraetive index and nuclear magnetic resonance (NMR) spectroscopy. Table 1 shows some data for three different liquids. 
TABLE 1

RESULTS OF THERMAL STABILTTY TESTTNG OF VARTOUS LIOUIDS

\begin{tabular}{|c|c|c|c|c|}
\hline \multirow{2}{*}{ Liquid } & \multirow{2}{*}{$\begin{array}{c}\text { Run } \\
\text { Duration }{ }^{1} \\
\text { (hr.) }\end{array}$} & \multirow{2}{*}{$\begin{array}{l}\text { Molecular } \\
\text { Weight } \\
\text { Reduction }{ }^{2} \\
\text { (\%) }\end{array}$} & \multicolumn{2}{|c|}{$\begin{array}{l}\text { Rate of Liquid Loss } \\
\text { (wt. \% of initial charge/hr.) }\end{array}$} \\
\hline & & & Maximum & Steady-State \\
\hline Drakeol@34 & 69 & 35 & 1.2 & 0.10 \\
\hline Durasyn $® 180$ & 65 & 86 & 1.8 & 0.12 \\
\hline & 73 & 3 & 0.095 & $0.00 \leq 0$ \\
\hline
\end{tabular}

1 - at a temperature of $375^{\circ} \mathrm{C}, \mathrm{H}_{2}$ pressure of 69 atma and $\mathrm{H}_{2}$ flow rate of 3.8 $\mathrm{sL} / \mathrm{min}$

2 - Initial minus End of Run/Initial

3 - at a $\mathrm{H}_{2}$ pressure of 59 atma.

Drakeol ${ }^{\circledR} 34$ is a saturated mineral oil comprised of 68 percent paraffins and 32 percent naphthenes. Durasyn ${ }^{\circledR} 180$ is a mixture of saturated oligimers of 1 decene. These two liquids are representative of those used as slurry media at lower temperatures with $\mathrm{Cu} / \mathrm{ZnO}$ catalysts $(1,7-13)$. Decalin ${ }^{\circledR}$ is a, tradename for decahydronaphthelene. Decalin was much more stable than either Drakeol 3! of Durasyn 180, as indicated by both of the liquid loss raies and by the insignificant reduction in molecular weight. NivR analyses $\left({ }^{1} \mathrm{H}\right.$ and $\left.{ }^{13} \mathrm{C}\right)$ carried out on samples of Decalin taken from the reactor at the end of the thermal stability test showed no evidence of hydrocracked products.

Performance of Commercial Catalyst

A commercial, "high-pressure" methanol synthesis catalyst (Zn-0312 II/8) was obtained from Engelhard Corporation in a reduced and stabilized form. The catalyst contained 60 wt. $\% \mathrm{Zn}$ and 15 wt. \% $\mathrm{Cr}$, with $\mathrm{ZnO}$ and $\mathrm{ZnCr}_{2} \mathrm{O}_{3}$ detectable by $x$-ray diffraction. The as-received BET surface area was $1 \pm 5 \mathrm{~m}^{2} / g$. The catalyst was ground and sieved to -120 mesh prior to use. All runs were made with a 20 wt. \% slurry of catalyst in Decalin. The catalyst was activated insitu by: pressurizing the reactor to 69 atma with $\mathrm{N}_{2}$ and heating it to $130^{\circ} \mathrm{C}$ while sparging $\mathrm{N}_{2}$ through the slurry; heating from 130 to $300^{\circ} \mathrm{C}$ at about $10^{\circ} \mathrm{C} / \mathrm{hr}$ with a sparge'gas consisting of $5 \% \mathrm{H}_{2}$ in $\mathrm{N}_{2}$; heating to $375^{\circ} \mathrm{C}$ at $25^{\circ} \mathrm{C} / \mathrm{hr}$ while 
progressively increasing the $\mathrm{H}_{2}$ mole fraction in the sparge gas from 0.05 to 1 , and; holding at $375^{\circ} \mathrm{C}$ with a pure $\mathrm{H}_{2}$ sparge until no water was present in the gas leaving the reactor.

Three series of experiments were conducted at total pressures of between 69 and 170 atma, temperatures in the range of 275 to $375^{\circ} \mathrm{C}$ and gas hourly space velocities (GHSV) between 1,500 and $10,000 \mathrm{sL} / \mathrm{kg}-\mathrm{hr}$. The feed was a mixture of $\mathrm{H}_{2}$ and $\mathrm{CO}$, with $\mathrm{H}_{2} / \mathrm{CO}$ ratios between 0.5 and 2. A typical operating pressure for a methanol synthesis process based on the "zinc chromite" catalyst is about 300 atma (14-16). The equilibrium concentration of methanol decreases as the pressure is decreased. In order'to limit the amount of methanol formed in a higher-alcohols process, the pressure probably will be lower than that used for methanol synthesis, in the region of those used in this research.

Figure 1 shows the product distributions that were obtained in two runs, one at $300^{\circ} \mathrm{C}$ and the other at $375^{\circ} \mathrm{C}$, at $5000 \mathrm{sL} / \mathrm{kg}-\mathrm{hr}$ GHSV, 68 atma total pressure and a $\mathrm{H}_{2} / \mathrm{CO}$ ratio of 0.5 . The carbon selectivity is defined as the percentage of the CO molecules that actually react that are converted to the products indicated. At both temperatures, methanol was the only alcohol in the outlet stream, and dimethyl ether (DME) was the only other oxygasiate present in significant quantities. DMIE probably formed by the condensation of two molecules of methanol, a reaction that is catalyzed by mildly acidic surfaces such as r-alumina (10). At $375^{\circ} \mathrm{C}$, a portion of the product, about $10 \%$ of the carbon atoms, was $\mathrm{C}_{2}$ through $\mathrm{C}_{4}$ olefins. Olefin formation in these quantities has not been reported previously for this type of catalyst in gas-phase, fixed-bed reactors. However, the formation of $C_{2}$ through $C_{-1}$ alcohols has been reporied $(5,6)$. Olefins may have resulted from the dehydration of the corresponding alcohol. The dehydration of isobutanol to isobutene is catalyzed by the same kind of acidic surfaces that catalyze the formation of DME from methanol (11). The paraffins formed at $375^{\circ} \mathrm{C}$ were predominantly methane with a small amount of ethane. The formation of a large quantity of $\mathrm{CO}_{2}$ demonstrates that the catalyst has a. substantial activity for the water-gas shift reaction. The water produced by the formation of alkanes, olefins and DME was snifted to $\mathrm{CO}_{2}$ essentially quantitatively.

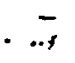


At $300^{\circ} \mathrm{C}$, methanol was the only product formed in substantial quantities. The production of hydrocarbons and dimethyl ether was small, which implies a low rate of water formation. This lack of water formation is responsible for the low apparent selectivity to $\mathrm{CO}_{2}$ at $300^{\circ} \mathrm{C}$ relative to the selectivity at $375^{\circ} \mathrm{C}$.

In Figure 2, experimentally measured rates of methanol production are compared to the rates that would be observed if chemical equilibrium were achieved. The catalyst productivity is defined as the rate of methanol formation (moles/hr) divided by the weight of catalyst in the reactor. The "equilibrium" catalyst productivity was calculated by assuming that the methanol synthesis reaction reached equilibrium in the gas stream leaving the reactor at the temperature of the reactor. For a pressure of 68 atma, the measured and theoretical rates are essentially equal at $375^{\circ} \mathrm{C}$ and are reasonably close at $350^{\circ} \mathrm{C}$. This suggests that the presence of Decalin did not have a significant inhibiting effect on the activity of the catalyst. On the contrary, the close approach to equilibrium at temperatures as low as $350^{\circ} \mathrm{C}$ is somewhat surprising. It has been reported (14) that the effectiveness factor of the pelleted, commercial zinc chromite catalyst is only about 0.7 in the temperature range from 370 to $410^{\circ} \mathrm{C}$. The good low-temperature activity of the catalyst in the slurry reactor may be associated to some extent with a reduction in the resistance to pore diffusion as a result of the much smaller particle size of the slurry catalyst.

As the reactor temperature was decreased at 68 atma, the difference betryeen the actual catalyst productivity and the equilibrium productivity increased. However, at $300^{\circ} \mathrm{C}$, the actual productivity of the catalyst.was higher than it was at any of the higher temperatures. This reflects the fact that the reaction equilibrium becomes more favorable as the temperature decreases. For comparison, the methanol productivity obtained with "zinc chromite" catalyst at $300^{\circ} \mathrm{C}$ is one-quarter to one-fifth of the productivity obtained with $\mathrm{Cu} / \mathrm{ZnO}$ catalyst in a slurry reactor at $250^{\circ} \mathrm{C}$ and otherwise comparable conditions (8).

Figure 2 also shows the methanol productivity as a function of temperature for a higher pressure, 137 atma, at the same feed composition and space velocity. The actual catalyst productivity increased with pressure by approximately a factor of two at constanit temperature. However, the difference between the actual and equilibrium productivities was greater than it was at 68 atma. The reaction 
kinetics appear to be substantially less sensitive to total pressure than the reaction equilibrium.

The longest of the experimental campaigns required over three weeks of continuous reactor operation. The liquid in the reactor at the end of this period was analyzed to determine whether any degradation had taken place. There was no decrease in the molecular weight. The catalyst productivity and the product distribution were measured periodically during the run at a standard set of conditions: $325^{\circ} \mathrm{C}, 5000 \mathrm{sL} / \mathrm{kg}-\mathrm{hr}$ GHSV, 69 atma and a $\mathrm{H}_{2} / \mathrm{CO}$ ratio of 2. The results are shown in Figure 3 . There was a modest decrease in the rate of methanol formation and a modest increase in the rate of paraffin formation with time. The BET area of the catalyst that was recovered at the end of the run was about $90 \mathrm{~m}^{2} / \mathrm{g}$, about $40 \%$ lower than the "fresh" value.

\section{CONCLUSIONS}

These studies are significant in several respects. First, sustained operation of a slurry reactor at $375^{\circ} \mathrm{C}$ and high $\mathrm{H}_{2}$ partial pressures, with no apparent degradation of the slurry liquid, represents a significant extension of the operating range for this type of reactor. The commercial "zinc chromite" catalyst appears to be compatible with slurry reactor operation in that a high level of activity was observed, there was no catastrophic deactivation of the catalyst over more than three weeks of continuous operation, and the catalyst did not appear to cause any degradation of the sluriy liquid. Some features of the product distribution at $375^{\circ} \mathrm{C}$ are encouraging, particularly the formation of substantial quantities of dimethyl ether and olefins. The high production rates of paraffins are a negative element of catalyst performance, to be addressed in future research.

\section{LITERATURE CITED}

1. Heydom, E. C., Schaub, E. S., Stein, V. E. E., Underwood, R. P. and Waller, F. J., "Recent Progress on Syngas Conversion to Isobutanol", paper presented at U. S. Department of Energy, Pittsburgh Energy Technology Center Coal Liquefaction and Gas Conversion Contractor's Review Conference, Pittsburgh, PA, September 7-8 (199년) 
2. Minahan, D. M. and Nagaki, D. A., "Heterogeneous Catalytic Process for Alcohol Fuels from Syngas", paper presented at U. S. Department of Energy, Pittsburgh Energy Technology Center Coal Liquefaction and Gas Conversion Contractor's Review Conference, Pittsburgh, PA, September 7-8 (1994)

3. Forzatti, P., Tronconi, E. and Pasquon, I., Catal. Rev. - Sci. Eng., $33(1 \& 2), 109$ (1991)

4. Riva, A., Trifiro, F., Vaccari, A., Busca, G., Mintchev, L., Sanfilippo, D. and Manzatti, W., J. Chem. Soc., Faraday Trans. 1, 83, 2213 (1987)

5. Tronconi, E., Lietti, L., Forzatti, P. and Pasquon, I., Applied Catalysis, 47, 317 (1989)

6. Tronconi, E., Lietti, L., Groppi, G., Forzatti, P. and Pasquon, I., J. Catal., 12A. 376 (1992)

7. Graaf, G. H., Winkelman, J. G. M., Stamhuis, E. J. and Beenackers, A. A. C. M., Chem. Engng. Sci., 43, 2161 (1988)

8. Roberts, G. W., Brown, D. MI., Hsiung, T. H. and Lewnard, J. J., Ind. Eng. Chem. Res., 32, 1610 (1993)

9. von Wedel, W., Ledakowicz, S. and Deckwer, W-D., Chem. Engng. Sci., 43 , 2169 (1988)

10. Brown, D. MI., Bhatt, B. L., Hsiung, T. H., Lewnard, J. J. and Waller, F. J., Catalysis Today, 8,279 (1991)

11. Armstrong, P. A., Bhatt, B., Heydon, E. C. and Toseland, B. A., "Isobutanol Dehydration: A Key Step in Producing MITBE from Syngas", paper presented at U. S. Department of Energy, Pittsburgh Energy Technology Center Coal Liquefaction and Gas Conversion Coniractor's Review Conference, Pittsburgh, PA, September 27-29 (1993)

12. Breman, B. B., Beenackers, A. A. C. M., Schuurman, H. A. and Oesterholt, E., Catalysis Today, 24, 5 (1995)

13. Roberts, G. W., Márquez, M. A. and MIcCutchen, MI. S., "Alcohol Synthesis in a High-Temperature Slurry Reactor", paper presented at U. S. Department of Energy, Pittsburgh Energy Technology Center Coal Liquefaction and Gas Conversion Contractor's Review Conference, Pittsburgh, PA, August 29-31 (1995) 14. Pasquon, I. and Dente, M., J. Catal., 1, 508 (1962)

15. Stiles, A. B., AIChE Jnl., 23,362 (197T)

16. Strelzoff, S., Chem. Eng. Prog. Symp. Series, No. 98, 66, 5ㄴ (1970) 


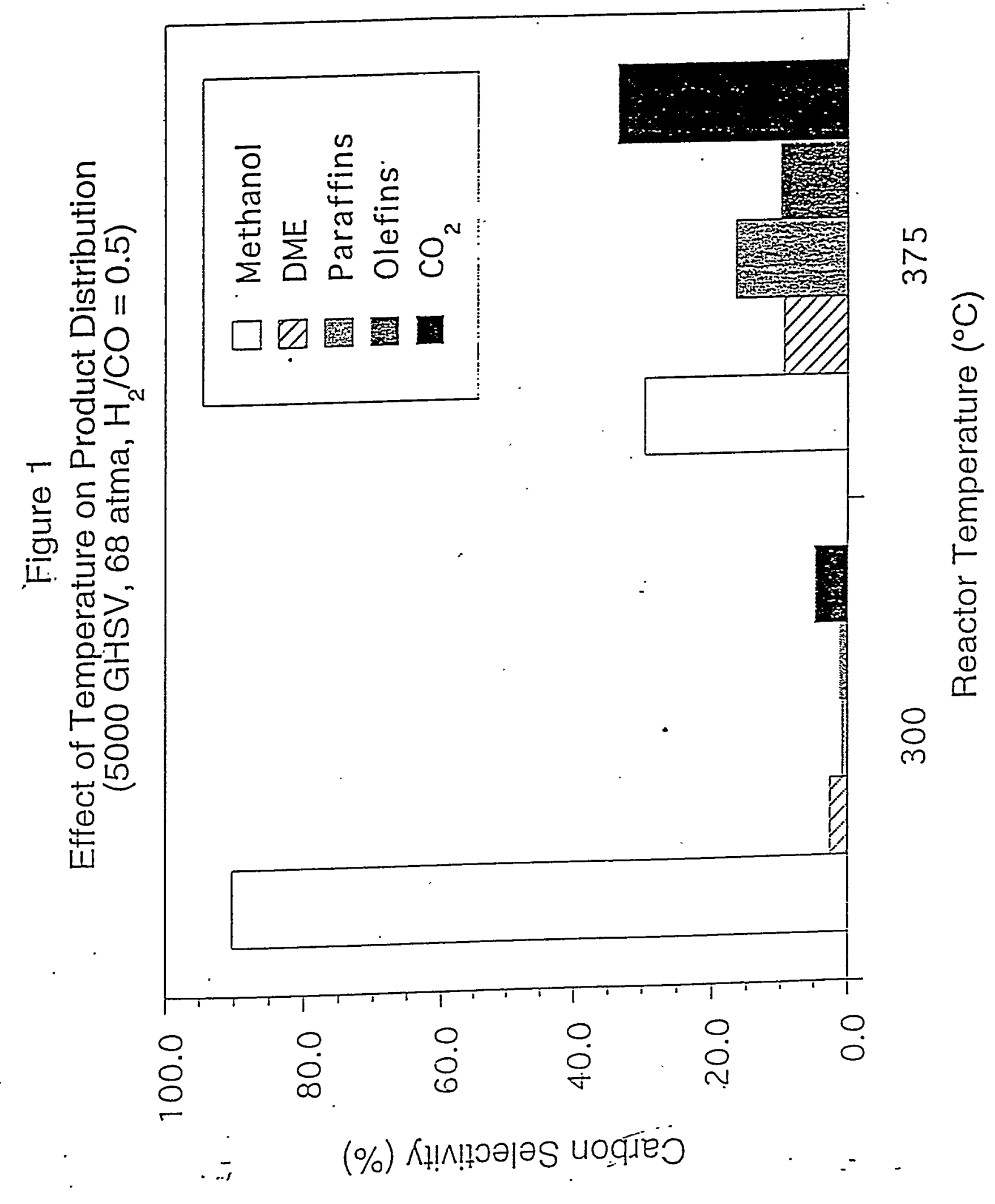




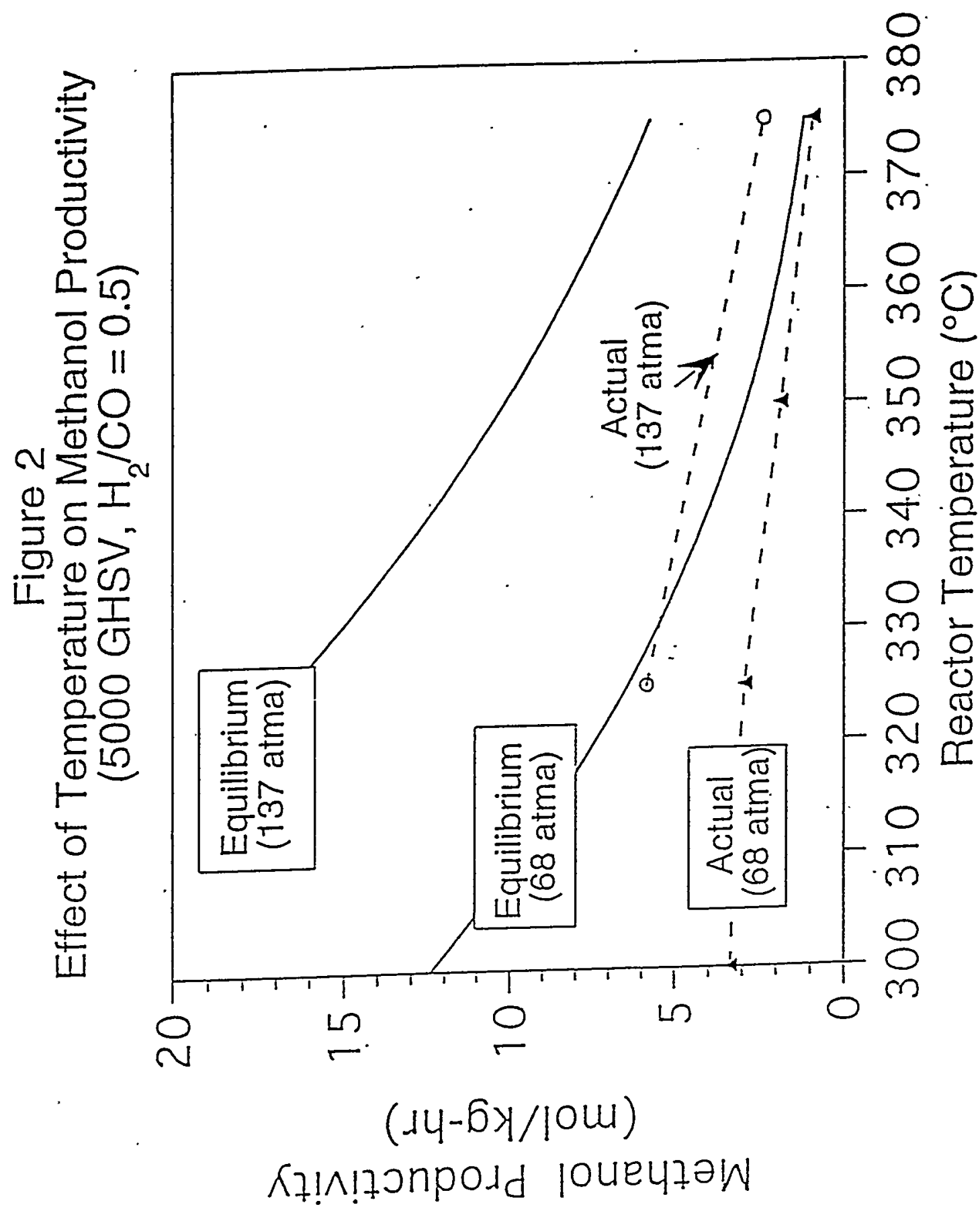




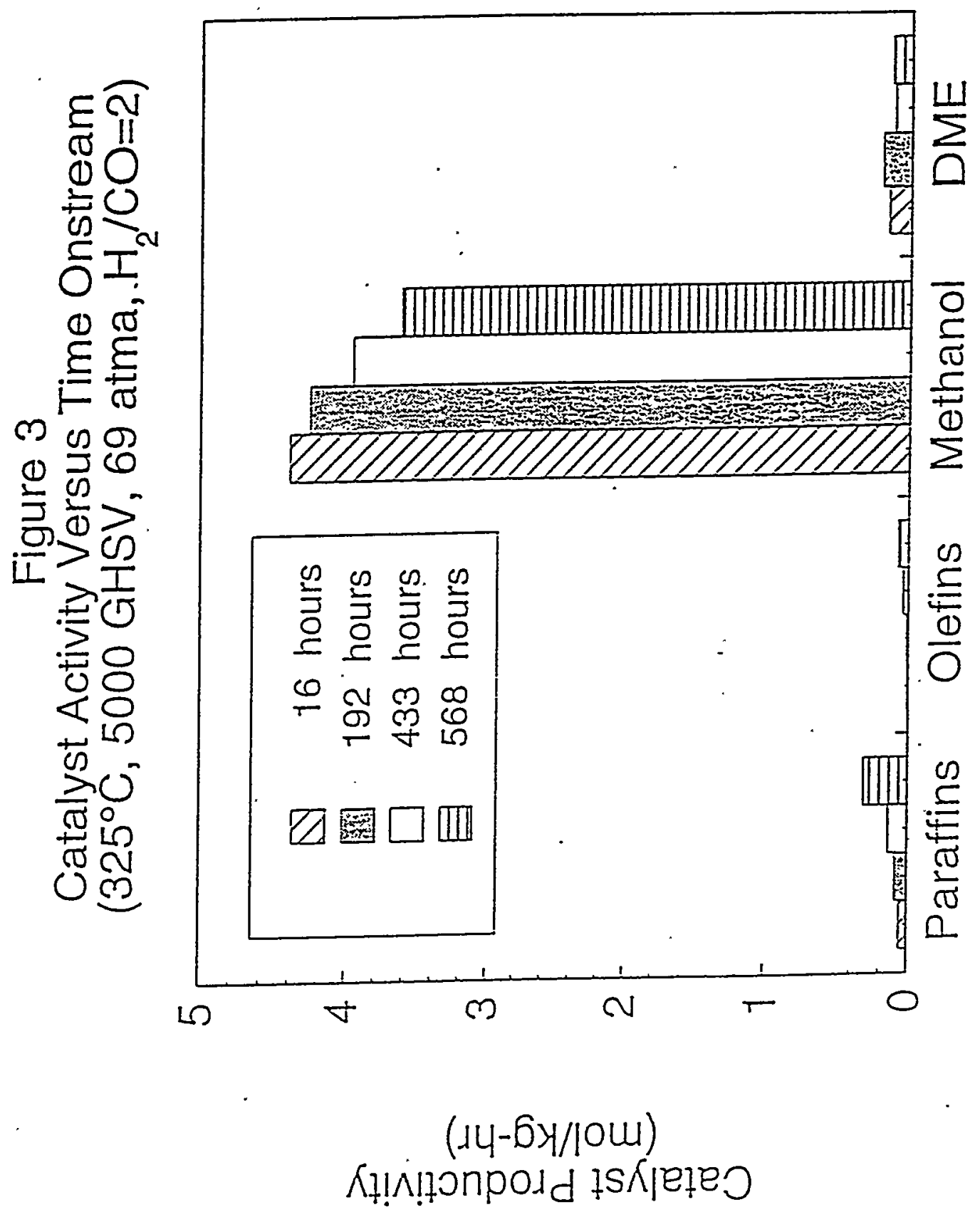

